\title{
蛍光体の合成プロセス \\ Synthesis Processing for Phosphor Materials
}

長谷川拓哉* • 戸田健 司*・金 善旭 ${ }^{* *} \cdot$ 佐藤峰夫***

Takuya HASEGAWA, Kenji TODA, Sun-woog KIM and Mineo SATO

Key Words: Phosphor, White LED, Solid State Reaction, Liquid Phase Reaction

\section{1. はじめに}

蛍光（ルミネセンス）とは、物質中の電子が電磁波や熱 などの外部からのエネルギーを受け取り、安定な基底状 態から不安定な励起状態に遷移して再び基底状態に戻る際 に、その受け取ったエネルギーを特定の波長の光（一般に は可視光）として放出する発光現象である。このルミネセ ンスの原理に基づいた発光を示す材料を蛍光体といい、特 に、応用を目的とした粉体あるいは薄膜材料を指すことが 多い1)。一般に蛍光体は、母体結晶中に発光イオンが取り 込まれることで作られており、発光イオンとしては遷移金 属イオンや希土類イオンが多く用いられている。その中で も特に 1960 年代以降、分離技術の確立によって希土類イ オンを発光イオンとした、希土類蛍光体が主流になってき た ${ }^{2}$ 。一方、母体結晶は発光イオンを取り込むためのただ の受け皿ではなく、発光イオンごとにその蛍光特性が変化 するために、発光イオンに応じて適切な母体結晶の選択が 必要である。これまで多くの研究者が様々な無機結晶材料 を母体結晶とする蛍光体の開発に取り組んできた。

発光デバイスにおける蛍光体の応用は、1920 年ごろのブ ラウン管用蛍光体 $\mathrm{CaWO}_{4}$ に始まり、次いで $\mathrm{ZnS}: \mathrm{Cu}, \mathrm{Ag}$ な どの硫化物蛍光体が広く研究され、1940年代に蛍光ラン プ・水銀ランプ用に $\mathrm{Zn}_{2} \mathrm{SiO}_{4}: \mathrm{Mn}^{2+}$ が用いられた ${ }^{3)}$ 。それ以 降、近年まで絶えることなく発光デバイスには蛍光体が用 いられてきた。1994 年には高輝度の青色 LED が上市され

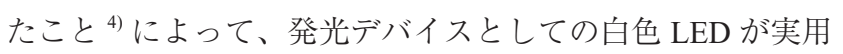
化された。白色 LED は青色 LED に黄色蛍光体もしくは緑 色蛍光体と赤色蛍光体を組み合わせることによって白色光 を得ている (Fig.1)。白色 LED は高輝度青色 LED の開発 からわずか 2 年ほどで実用化が始まり、現在すべての液晶

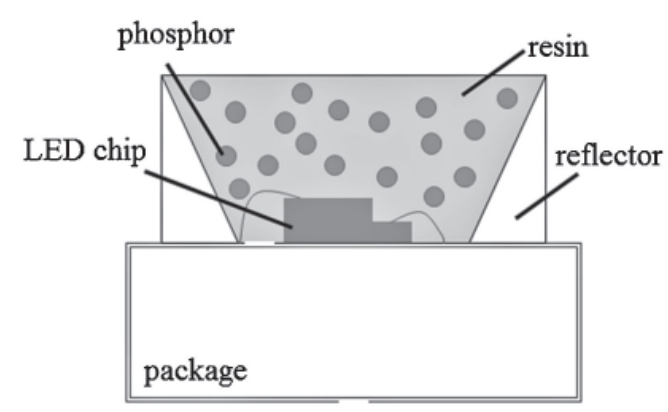

Fig.1 Schematic image of typical white LEDs.

ディスプレイ (LCD) のバックライトには白色 LED が用い られている。LCDの低コスト化および薄型化を実現し、テ レビからスマートフォンまでの様々な表示デバイスに利用 され、その伸長を大きく促進させた。しかし現在では、表 示デバイス分野の市場が十分に成熟したことで LED バック ライトの成長率は鈍化している。一方で、一般照明の分野 では更なる成長率の拡大が見达めることから、照明用とし ての新規蛍光体の開発や合成プロセスの開発・改良が活発 に行われている。

蛍光体粒子はその用途によって求められる形態が異な る。たとえば、白色 LED 用蛍光体のようなフォトルミネセ ンス（励起源を紫外線や可視光とする発光）の原理に基づ いて発光する蛍光体においては、一般に蛍光体粒子をサブ ミクロン程度まで小さくすると、発光が低下してしまう。 これは、粒子が小さくなることで、構造欠陥が多く発光効 率の低い結晶表面の割合が増大するためである。また、屈 折率の違う界面（例えば、空気と蛍光体）で光の反射が起 こるため、フォトルミネセンスに基づく発光を示す蛍光体

* 新潟大学自然科学研究科 ( $\bar{T} 950-2181$ 新潟県新潟市西区五十嵐二の町 8050)

Graduate School of Science and Technology, Niigata University (8050 Ikarashi 2-nocho, Niigata 950-2181 Japan)

* * Department of Nanotechnology and Advanced Material Engineering, Sejong University (209 Neungdong-ro, Gwangjin-gu, Seoul 05006, Republic of Korea)

$* * *$ 新潟大学 工学部 ( $\bar{\top} 950-2181$ 新潟県新潟市西区五十嵐二の町 8050)

Department of Chemistry and Chemical Engineering, Niigata University (8050 Ikarashi 2-nocho, Niigata 950-2181 Japan) 
は大きければ大きいほど良い。しかしながら樹脂と蛍光体 を混合する白色 LED では、大きすぎると樹脂内で蛍光体粒 子が沈降してしまうため、10～30 $\mu \mathrm{m}$ 程度の粒子を利用し ている5 。単結晶シリコン太陽電池用の波長変換材として の蛍光体では、光吸収効率を犠牲にしてでも透明性を確保 する必要があるため、50 nm 以下のナノ粒子が求められる。 このように、蛍光体材料においては、その用途に応じて適 切に粒子形態の制御が必要不可欠であり、すなわち、その 適切な合成プロセスの選択が極めて重要であるといえる。

本解説記事では、まず蛍光体材料に対して、最も汎用的 に用いられる固相反応法の基礎的な操作および合成ノウハ ウについて述べる。その後は、蛍光体材料によく用いられ る溶液法を、特に白色 LED 用蛍光体の合成を例にとって、 それらの合成方法や合成プロセスを述べる。さらに、近年 注目される蛍光体の合成プロセスについて述べることで、 最新動向を説明する。

\section{2. 蛍光体合成における固相反応法の基礎}

前述のとおり、フォトルミネセンスの原理に基づく蛍光 体、特に白色 LED 用蛍光体においては比較的巨大な粒子が 望まれる ${ }^{5)}$ 。したがって、希薄系である気相法のような微 粒子を合成する手法よりも、古典的な固相反応法や液相法 による合成がよく用いられる ${ }^{5}$ 。中でも最も簡便で広く用 いられる固相反応法は、固体表面間のイオン拡散が律速と なるため、成長した粒子の作製には高い反応温度や長い反 応時間を要する。Fig.2に典型的な固相反応法を用いた蛍 光体材料の合成フローチャートを示す。固相反応法では、 通常、粉体原料を出発原料として用い、秤量、混合を経て 焼成過程に移る。多くの場合、仮焼成の後に本焼成を行う。 以下に、各ステップの詳細な操作を述べる。

蛍光体において、発光イオン以外の不純物は発光効率の 低下を招く場合 (キラー効果) がある。特に、古くから使 用されてきた硫化物蛍光体においては Fe や Ni、Co といっ た鉄族の遷移金属がわずか $10 \mathrm{ppm}$ 程度混入するだけで約半

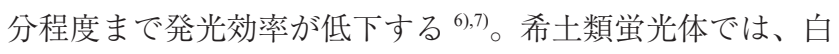
色 LED 用として使用される窒化物蛍光体においては、結晶 格子への酸化物イオンの混入が発光効率を低下させる。し たがって、可能な限り高純度の原料を使用することが望ま しい。複合酸化物といった複数成分を含む化合物の合成に は、それらの原料の中でも特にイオン拡散の律速となる成 分が最終的な蛍光体の形態を決めることが多いために、そ のような粒子は反応性の高い出発物質を選択することが重 要である。出発原料として適した粉体は反応活性が高いた めに、表面に水分や炭酸ガスの吸着が懸念されることから、 原料の秤量前には熱分析で出発物質の実際の量を正確に決 定しておくことが必要となる。特に、発光イオンとしてよ く用いられる希土類酸化物は水分や炭酸ガスを容易に吸着 することが知られており、希土類の種類によって、吸着量

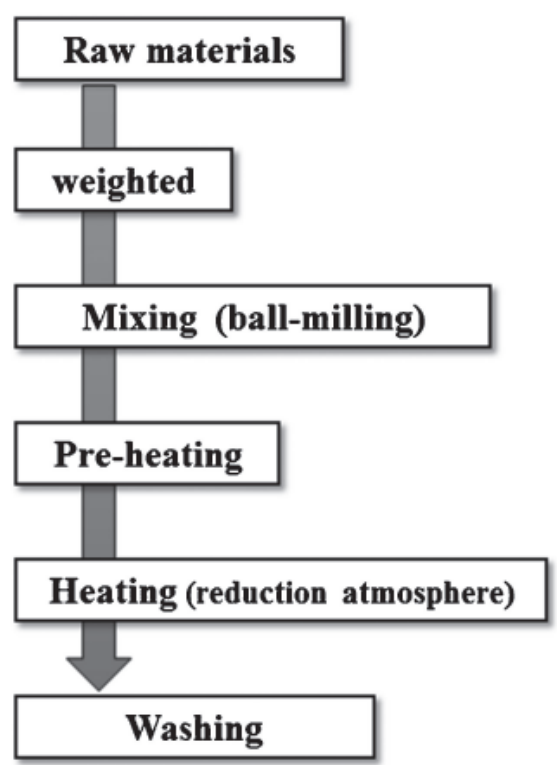

Fig.2 Flowchart of typical solid-state reaction method for phosphor materials.

は異なってくる。中でも、酸化ランタン $\left(\mathrm{La}_{2} \mathrm{O}_{3}\right)$ は加熱処 理直後すぐに重量増加が見られるほど水分の吸着に敏感で ある。したがって、原料を取り扱う上で、化学量論比の通 りに正確に仕込むことは困難、かつ極めて重要である。

通常の固相反応法を用いた蛍光体の合成においては、前 述のとおり原料の均一化が重要であるため、その混合プロ セスには均質混合が期待できるボールミル混合が一般的で ある。容器の自転と公転の両回転による強いエネルギーで 混合する遊星ボールミルでは、破砕エネルギーが強すぎて 粒子表面の欠陥をもたらすために、適度な強度での混合が 期待できる横型ボールミルが望ましい。アルミナやジルコ ニア、炭化ケイ素製ボールからの不純物が混入されること もあるため、その回転速度などには十分に注意を払う必要 がある。混合の際に溶媒を使用する場合は、水は安価で取 り扱いが容易であるが、蛍光体材料には水溶性原料が使用 されることも多いために比較的安価で揮発性のエ夕ノール やアセトンといった有機溶媒もよく使用される。原料によっ ては単純な酸化物でも有機溶媒に無視できない量の溶解 が見られる場合があるため、化学物質等安全データシート (SDS) などを利用してあらかじめ調査しておく必要がある。 一方で、蛍光体中の発光イオンは通常数 \% 程度と微量であ るため、均一分散させるために、溶液として添加すること もしばしばみられる。湿式混合の場合、単純に容器内で乾 燥させた場合では、原料粉体の比重差、溶解度や乾燥速度 の違いによって不均一化してしまうため、ロータリーエバ ポレー夕等の機器で均一性を確保したまま乾燥処理する。

混合した原料混合物は、本焼成の前に仮焼を行うことが 一般的である。これは、原料中の炭酸塩や有機金属塩など 
の原料物質から放出されるガス成分の除去以外に、発光イ オンの組成変動を小さくするといった役割も兼ねている。 硫酸塩や硝酸塩を用いた場合においては、分解ガスは大気 中濃度が低いために雲囲気に対する依存度は小さい。しか しながら、シュウ酸塩や酢酸塩などの有機系の塩を用いた 前駆体では、水分や炭酸ガスなどの周囲の影響を強く受け る。また、より良質な最終生成物を得るためには仮焼温度 には注意を払う必要がある。仮焼温度が高すぎると、粒子 が過剩成長してしまう。一方、温度が低すぎると有機物や 未分解塩の残留により本焼成過程でガス放出が生じるた め、仮焼温度は慎重に設定する必要がある。仮焼温度を決 定するためには、事前に熱分析やX 線回折、比表面積測 定などのキャラクタリゼーションをしておくことが望まし い。仮焼で炭素残留量が多い場合は、水でバブリングした 空気を導入するなどして雲囲気に水蒸気を取り入れること でうまく除去することが可能である。これは、水蒸気が高 温下で高活性なラジカルとなることで有機物の酸化分解を 促進するためであると考えられている。

本焼成では、蛍光体母体や発光イオンの種類によって、 焼成時の雲囲気が異なる。白色 LED 用蛍光体によく用いら れる $\mathrm{Eu}^{2+}$ や $\mathrm{Ce}^{3+}$ を発光イオンとする場合は、窒素－水素混 合ガスなどの還元䨌囲気で焼成することが多い。これは、 原料として $\mathrm{Eu}^{3+}$ や $\mathrm{Ce}^{4+}$ の価数をとる $\mathrm{Eu}_{2} \mathrm{O}_{3}$ および $\mathrm{CeO}_{2}$ を 用いる場合が多いため、 $\mathrm{Eu}^{2+}$ および $\mathrm{Ce}^{3+}$ の $5 \mathrm{~d}-4 \mathrm{f}$ 遷移によ る発光を得るためには、 $\mathrm{Eu}^{3+} \rightarrow \mathrm{Eu}^{2+}$ あるいは $\mathrm{Ce}^{4+} \rightarrow \mathrm{Ce}^{3+}$ への還元が必要であるためである。しかし、水素ガスを用 いた還元䨌囲気下での焼成では安全面から水素ガス濃度は 爆発限界下限值である 5 vol\% を超えないようにする必要が ある。仮焼時は水蒸気が有機物の分解をアシストすること からその導入は効果的であったが、還元雲囲気下での本焼 成時はむしろ問題となる。前述の通り、水蒸気は高温下で 活性の高いラジカルに変化するために、還元雲囲気下では、 強い酸化剂として働いてしまう。したがって、本焼成前に は、あらかじめ可能な限り粒子表面に吸着されている水分 を除去しておく必要がある。

蛍光体の発光特性は粒子表面の状態に強く依存するた め、蛍光体の本焼では、生成物の結晶性の向上や粒子形態 の制御、粒子表面の改質などを目的として、融剤（フラッ クス）を用いることがよくある ${ }^{8)}$ 。例えば赤色発光 $\mathrm{Ca}_{2} \mathrm{SiO}_{4}$ $: \mathrm{Eu}^{2+}$ 蛍光体は、フラックス処理により蛍光特性の大幅な改 善が見られ、白色 LED 用の赤色蛍光体として大きな注目を 集めている ${ }^{8), 9)}$ 。 $\mathrm{Ca}_{2} \mathrm{SiO}_{4}: \mathrm{Eu}^{2+}$ 蛍光体において $\mathrm{BaCl}_{2}$ を用い フラックス処理を行うことによって市販の黄色蛍光体であ る $\mathrm{YAG}: \mathrm{Ce}^{3+}$ 蛍光体 $(\mathrm{P}-46)$ と同等の発光ピーク強度を持つ 高輝度な赤色発光を示すが、フラックスを添加しない場合 には、発光そのものが観測されない場合もある(Fig.3 $)^{8), 99}$ このように、蛍光体におけるフラックスの添加は大きな蛍 光特性の向上をもたらし、必要不可欠なプロセスとなるこ

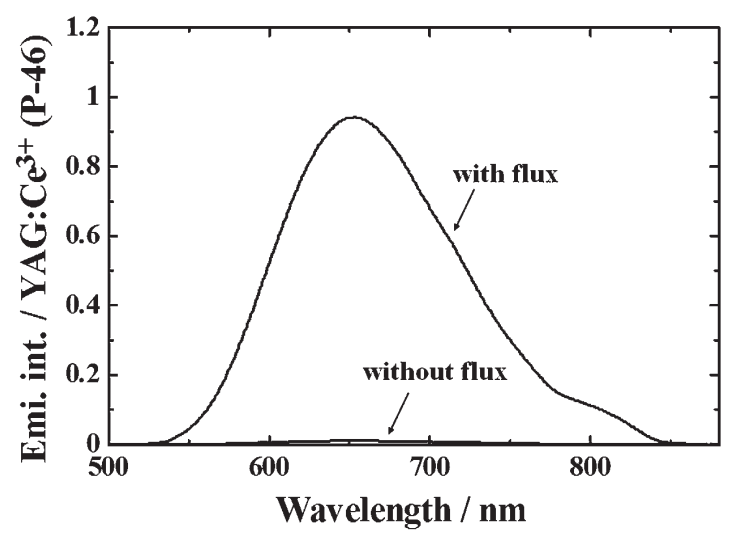

Fig.3 Emission spectra of the $\mathrm{Ca}_{2} \mathrm{SiO}_{4}: \mathrm{Eu}^{2+}$ phosphors synthesized with/ without $\mathrm{BaCl}_{2}$ flux.

とがある。蛍光体におけるフラックスの働きとしては粒子 径の制御に加え、還元の促進を目的とする場合もある。粒 子径の制御には、他のセラミックス材料に拈けるフラック スと同様に $\mathrm{NaF}$ や $\mathrm{SrCl}_{2}$ などの金属のハロゲン化物など低 融点材料が用いられる。 $\mathrm{Eu}^{2+}$ の還元作用を期待する場合 には、ハロゲン化アンモニウム $\left(\mathrm{NH}_{4} \mathrm{~F} や \mathrm{NH}_{4} \mathrm{Cl}\right)$ がよく用 いられる。還元作用の増大は、 $\mathrm{EuF}_{2}$ または $\mathrm{EuCl}_{2}$ の形成に よると考えられている。目的とする蛍光体は、固有の融点 および沸点を有するため、取り扱うフラックスの化学的 · 物理的性質を十分理解し、適切にフラックスの種類および 処理温度を選択する必要がある。フラックスの効果を期待 するためには、フラックスが融解することが必要条件とな る。目的の材料が結晶化する際に、その結晶表面での溶解、 再析出による表面の平坦化を促進するために、融解したフ ラックスの存在が必要となる。加えて、融解したフラック スが物質拡散を促進させるため、合成温度を低下させるこ とも可能である。しかし、フラックスの融点あるいは沸点 が原料同士間の反応温度より低すぎる場合はフラックスの 効果が少なくなる。また、フラックスは最終生成物に残存 しやすく、これは蛍光体の発光特性を低減させる原因とな るため、フラックス処理を行った場合はイオン交換水やア ルコールなどで洗浄が必要である。このように、フラック ス処理は従来の蛍光体の開発において重要な役割を担って いるが、実用蛍光体についてどのようなフラックスがより 効果的かは、ノウハウとしてほとんど公開されていないの が現状である ${ }^{8)}$ 。したがって、実際の実験を通して、フラッ クス種やその添加量を最適化する必要がある。

反応容器となるルツボは蛍光体の母体結晶の種類により 使い分けられ、酸化物蛍光体ではアルミナや炭化ケイ素系、 窒化物蛍光体では窒化ホウ素系の容器が用いられる。量産 では、ガスとの接触を改善するためにルツボ以外にも平底 の皿状容器 (“さや”と呼ばれる) が用いられることもある。 しかし、多くの場合にこれらの容器には焼結助剂が含まれ 
ている。高純度アルミナ容器においてもシリカ、窒化ホウ 素容器の場合には酸化カルシウムが添加されており、蛍光 体粒子の污染の原因となりうるため十分に注意する必要が ある。

焼成時に使用する電気炉は、実験室レベルでは箱型もし くは管状炉が使用される。箱型炉では完全な密閉が困難で あるために、外部から空気が混入しやすく、還元反応が不 十分となる場合がよくある。一方、管状炉では密閉系にし やすいために、還元䨌囲気下での焼成には適している。し かし、手作りの管状炉ではシリコーンゴムで封止するこ とが多いが、シリコーンは水蒸気透過性が高いために、そ の侵入を防ぐために耐熱アルミテープなどを目貼りして対 策を講じる必要がある。また、企業での大量生産にはプッ シャー炉などの連続炉を用いることもある。プッシャー炉 とは、耐火物の台板の上に焼成品を置いて、台板を押し出 すことにより炉内を搬送する装置である。プッシャー炉で は、製品の導入部および排出部は減圧室となっており、炉 内に外気が混入することが少ない。また、焼成する蛍光体 に対して、内部容積が大きいことから、雾囲気ガスが蛍光 体からの放出ガスの影響を受けにくい。前述の、容器から の污染も併せ、蛍光体の製造は可能な限りより大きいロッ トで行うことが望ましい。

高温焼成後の蛍光体粒子は凝集しているため、粉砕する 必要があるが、機械的な強い粉砕は蛍光体粒子表面を傷つ けてしまい、蛍光特性の低下を引き起こす。さらに、粒子 径にばらつきが大きいと、発光効率の低下を招くためその 分布をそろえることが重要となる。したがって、適度な粉 砕と洗浄などの処理を施したのちに、ふるいなどの分級操 作を行うことが望まれる。

\section{3. 蛍光体合成における溶液法}

固相反応法は単純かつ簡便な手法であり有用であるが、 固相反応法により合成された材料のイオン分布や粒子径は 不均一になりやすく、組成制御が困難である問題を抱えて いるのも事実である。これは、先に述べた通り固相反応法 では陽イオンの拡散を促進させるために高温焼成が必要で あることが原因である。この材料組織の不均一化は、反応 粒子のサイズを小さくすることで解決できる。微粒子化さ れた前駆体を利用することで成分間の混合状態が改善され、 場合によっては低温での反応が可能となる。溶液法はその ような微粒子の合成、つまり均一な材料組織を持つセラミッ クス材料の合成手段として有用であり、もちろん蛍光体材 料に対しても有効である。溶液法には様々な手法があるが、 どの溶液法でも同様のスキームを経る。Fig.4に溶液法に共 通する合成スキームを示す。いずれの溶液法においても、 均一溶液を出発として、様々な化学プロセスを用いて、均 一な前駆体を作製する。単純な溶液の乾燥では均一性は得 られない。次いで、作製した均一な混合前駆体を熱処理す
ることで目的材料を作製するといった流れとなる。化学プ ロセスの種類によって溶液法の名称が決められる。たとえ ば、化学プロセスとしてオートクレーブを用いた水熱処理 を用いる場合「水熱法」、原料溶液を添加した溶媒をゾルか らゲル化させた後、熱処理を行う場合「ゾルゲル法」など と呼ぶ。このように、化学プロセスは前駆体の均一性を左 右するため、最終的な材料特性（蛍光体においては特に蛍 光特性）に影響する。ここでは、蛍光体合成における代表 的な溶液法について具体例を挙げながら解説する。

セラミックス材料の合成に広く用いられる共沈法は、蛍 光体の合成プロセスとしても優れている。共沈法は、目 的とする 2 種類以上の金属イオンから成る溶液から沈殿剂 の添加などの化学的処理を施し、溶液中のイオン濃度を溶 解度積以上の過飽和状態にすることで、難溶性塩（水酸化 物、炭酸塩、リン酸塩、硫酸塩など）を同時に沈殿生成さ せる方法である。この方法では、条件を適切に選べば複数 種の金属イオンが均一に分散した沈殿物が得られる。緑色 蛍光体 $\mathrm{LaPO}_{4}: \mathrm{Ce}^{3+}, \mathrm{Tb}^{3+}$ は共沈法によって合成される代表 的な市販蛍光体材料である。 $\mathrm{LaPO}_{4}: \mathrm{Ce}^{3+}, \mathrm{Tb}^{3+}$ は紫外線 $(254$ $\mathrm{nm})$ の励起下において $\mathrm{Tb}^{3+}$ 由来の $555 \mathrm{~nm}$ 付近の緑色領域 に鋭い発光バンドを有し、高い発光効率を持つことから蛍 光ランプ用の緑色蛍光体として最も広く用いられている。 $\mathrm{LaPO}_{4}: \mathrm{Ce}^{3+}, \mathrm{Tb}^{3+}$ は、 $\mathrm{La}^{3+} 、 \mathrm{Ce}^{3+}$ および $\mathrm{Tb}^{3+}$ の硝酸塩などの 水溶性塩にリン酸を加えることで、 $\mathrm{Ce}^{3+} や \mathrm{~Tb}^{3+}$ が均一に分 散固溶した希土類リン酸塩の前駆体が沈殿する。この前駆 体（この状態ですでに結晶化している）を加熱処理するこ とで簡単に単一相のリン酸ランタンを得ることができる。 このように、共沈法は非常に簡便かつ効果的な蛍光体の合 成手法である。

さらに近年では、共沈法の他に、錯体重合法を用いて合 成された蛍光体材料が興味深い特性を示すことで注目を集

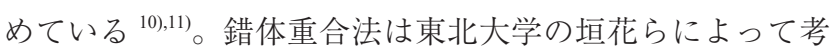

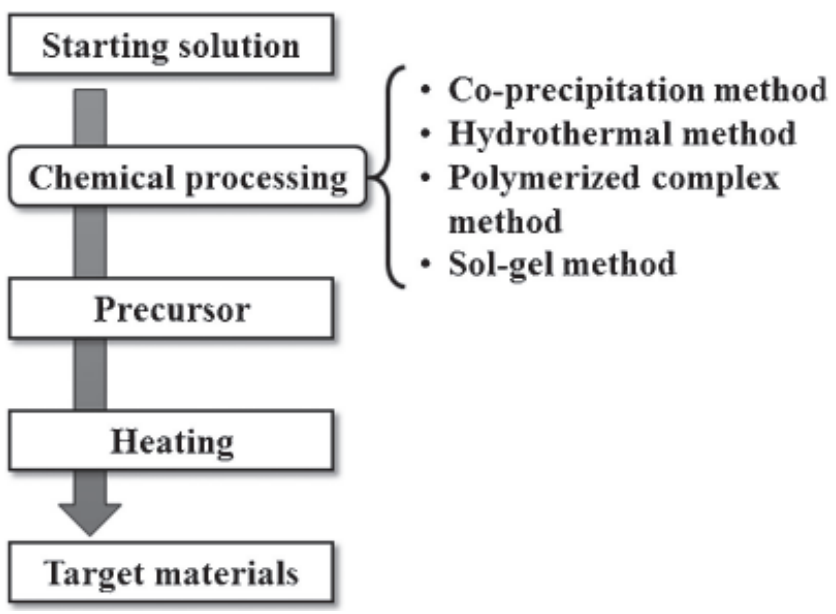

Fig.4 Flowchart of the typical liquid phase reaction method. 
案された手法であり、金属錯体を有機物と重合させること

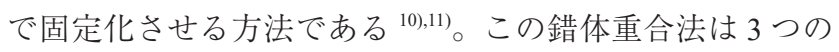
ステップから成る。第 1 ステップとして、クエン酸のグリ コール溶液に金属源を溶解させ、金属クエン酸錯体を形成 させる。第 2 ステップでは、有機化学の基本反応であるエ ステル化により金属を含有したポリエステルを作製する。 ジカルボン酸（クエン酸）中の末端カルボン酸基 HCOO-R$\mathrm{COOH}$ とグリコールのヒドロキシル基 HO-R'-OH との脱水 縮合反応が化学的プロセスによって前駆体が得られる。最 後に、第 3 ステップでは、ポリエステルや過剩のクエン酸、 グリコールといった有機物を加熱処理することで除去す る。一般的には $500{ }^{\circ} \mathrm{C}$ 程度での加熱だけで十分だが、場合 によっては目的物質の反応温度に応じて更なる加熱を必要 とする ${ }^{12)}$ 。錯体重合法は金属錯体をポリエステル樹脂中に 物理的に閉じ込めるため、錯体を形成する金属種のほとん どで合成が可能であり、多種多様な材料を合成することが できる。共沈法では、成分数が増えた場合、すべての成分 種を共通し、均一に沈殿できる条件を見出す、また反応容 器のすべてにわたって均一性を確保することは難しい。一 方で、錯体重合法は固体状態において成分が強制的に固定 化されているので複雑な化学組成も簡便かつ均質に合成で きる点が利点である。通常、蛍光体には $1 \mathrm{~mol} \%$ オーダー(材 料によってはその 10 分の 1) の発光イオンが含まれる。さ らに、母体結晶の化学組成も 3 元系以上の場合が多く、蛍 光特性の細かなチューニングをするとなると 5 元系以上に 達する場合もある。したがって、複雑な化学組成をとるこ とがよくある蛍光体にとって、垣花らが提案したこの新し い錯体重合法は優れた手法である。

蛍光体の合成にとって非常に優位性の高い錯体重合法で はあるが、クエン酸やグリコールなどの有機物を使用する ため、生産コストが増大する。その中で、錯体重合法が最 も効果を発揮する領域は、「物質探索手法」ならびに「材 料特性の限界を知る」といった点にある ${ }^{12)}$ 。錯体重合法 を利用した溶液並列合成法は、新規蛍光体の高速探索法と して応用されている。この手法により、従来の固相法では 膨大な時間を要する探索に対して短時間での開発が可能で あることから、実際に、様々な新規蛍光体の発見や蛍光体 の高機能化を実現した。特に垣花らは低温での合成が可能 な点や熱安定性の高さからリン酸塩蛍光体に着目し、溶液 並列合成法を利用した蛍光体の探索を試みた。その結果、 $\mathrm{Sr}_{9} \mathrm{M}_{(}\left(\mathrm{PO}_{4}\right)_{7}: \mathrm{Eu}^{2+}(\mathrm{M}=\mathrm{Y}, \mathrm{Gd}, \mathrm{Sc})$ 蛍光体において興味深い蛍 光特性を示した。得られた蛍光体は $400 \mathrm{~nm}$ の近紫外光下 で $520 \sim 570 \mathrm{~nm}$ に最大発光ピークを持つ緑色から黄色発

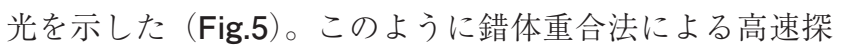
索手法は、所望する蛍光特性を有する材料を効率よく探索 可能で、その特性のポテンシャルを短期間で知ることがで きる有用な手法である。

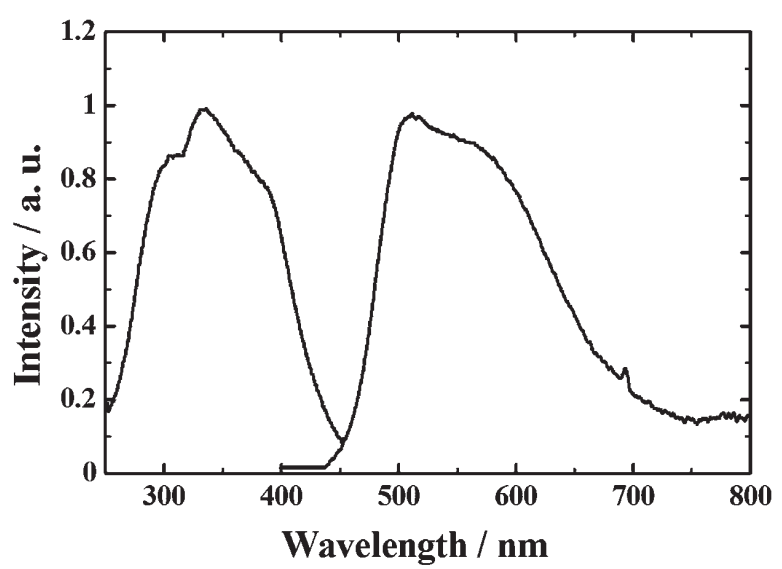

Fig.5 Excitation and emission spectra of the $\mathrm{Sr}_{9} \mathrm{Sc}\left(\mathrm{PO}_{4}\right)_{7}: \mathrm{Eu}^{2+}$ phosphor synthesized by the polymerized complex method.

\section{4. 蛍光体合成における最新手法}

近年、当研究室では集光炉を用いた溶融合成法による蛍 光体材料の開発を検討している。集光炉とは、キセノン アークランプなどのアーク放電による放射エネルギー（高 密度な光エネルギー）をランプ周囲に設置されたアルミニ ウム楕円ミラーで一点に集光させることで、粉体試料を加 熱溶融することができる特殊な電気炉である ${ }^{13)}$ 。集光炉の 模式図を Fig.6 に示す。当研究室が所有する集光炉は $6 \mathrm{~kW}$ と高出力のキセノンアークランプを用いるため、集光部は 約 $2000{ }^{\circ} \mathrm{C}$ 程度まで短時間で上昇させることが可能である。 特に単結晶育成には、集光炉の光源として高出力で安定か つ長寿命であるレーザを使用することもあるが、原料に よっては特定のレーザ波長に対する吸収率が低く加熱のム ラが生じやすく、また加熱に時間を要するという問題点も ある。キセノンアークランプの放電は紫外光から赤外領域 まで太陽光スペクトルによく似たスペクトルを持つことか ら、酸化物原料によらず安定して高温までの加熱が可能で ある ${ }^{14)}$ 。そのため、多成分の原料を扱う場合は光源として キセノンアークランプを用いる方が適している。また、試 料室内の雲囲気を酸化あるいは還元など様々な䨌囲気に変 化させることも可能であるため、3 価の希土類イオンを発 光イオンとする蛍光体だけではなく、 $\mathrm{Eu}^{2+}$ や $\mathrm{Ce}^{3+}$ を含むよ うな還元処理が必要な蛍光体の作製にも適している。銅製 試料台の下部には冷却水が流れているため、焦点から十分 に距離を置くことで急速な冷却が可能となる。集光炉で合 成された蛍光体は通常、溶融状態で結晶成長し冷却される ため、数ミリメートルオーダーの球状試料として得られる。 反応時間は 1 分未満でかつ冷却時間がわずか数秒程度であ るため、多くの場合、単結晶ではなく焼結した多結晶体と して得られる。集光炉を用いた溶融法による蛍光体の合成 で、最も本領を発揮するのは、その反応時間の短さを利用 した蛍光体の高速探索にある。通常の固相反応では、数時 


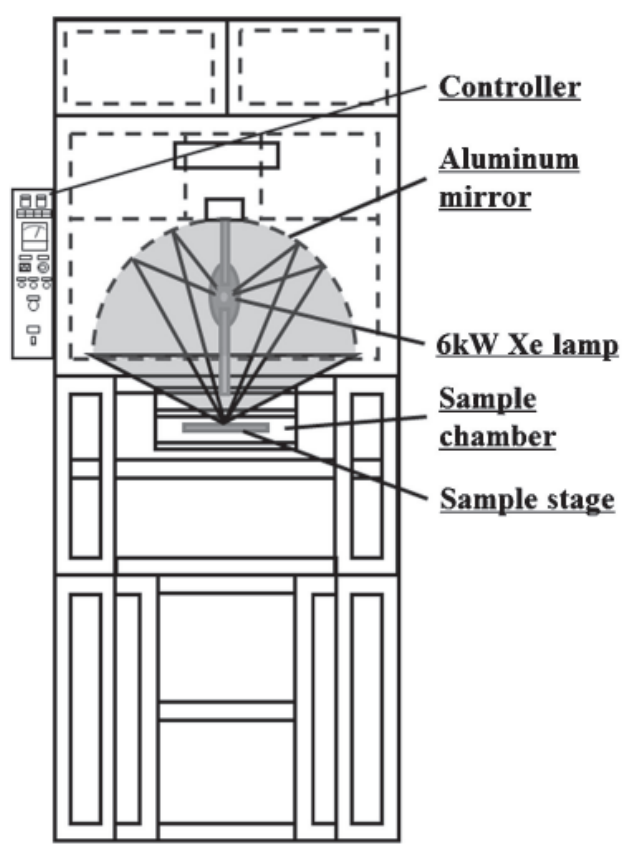

Fig.6 Optical system of the arc-imaging furnace.

間を要する反応でも、集光炉を用いた溶融法ではわずか数 分の合成時間しか必要とせず、溶融状態での反応であるた め、溶液法のような均一なイオン拡散が見込めるため、試 料の均一性も保証できる。実際に、高速探索法としての用 途で、様々な興味深い蛍光特性を有する蛍光体の開発に成 功してきた。さらに、集光炉を用いた溶融法では高温にお ける溶融合成と共に、冷却時間が非常に短いため、一般の 固相法では合成しにくい、高温相のセラミックス材料を容 易に合成することも可能である。たとえば、 $\mathrm{Eu}^{2+}$ を賦活し たリン酸塩について集光炉を用いた溶融法で網羅的に探索 した結果、赤色発光 $\mathrm{NaMgPO}_{4}: \mathrm{Eu}^{2+}$ 蛍光体の合成に成功し た ${ }^{15)}$ 。 $\mathrm{NaMgPO}_{4}$ は従来、ただ一つの結晶相（グラセライト 相）しか確認されていなかったが、集光炉を用いた溶融合 成によって、新規な結晶相であるオリビン相を持つことが 明らかになり、 $\mathrm{Eu}^{2+}$ が固溶したオリビン型 $\mathrm{NaMgPO}_{4}$ 蛍光 体は青色励起下において $628 \mathrm{~nm}$ を最大ピークとする赤色 発光を示した ${ }^{15}$ 。 この蛍光体は、白色 LED 用の赤色蛍光体 に求められる諸特性と合致していることから、白色 LED 用 赤色蛍光体として期待されている。その他には、組成内に ケイ素やリン、ホウ素などのガラス化しやすい成分を組み 込むことで、発光性ガラスも容易に作製できる ${ }^{16 。}$

蛍光体材料において、母体の結晶構造は蛍光特性に大き な影響を与えるため、蛍光体の蛍光特性の向上や蛍光体 そのものの設計には、結晶構造の理解すなわち発光イオン 周囲の配位環境の特定は極めて重要である。しかしなが ら、一般に発光イオンの濃度が微量であることから、粉体 の状態での結晶構造解析は困難である。したがって、蛍光

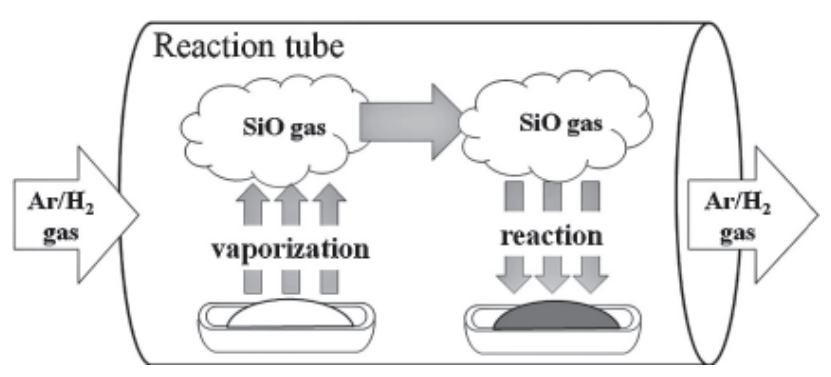

Fig.7 Schematic image of reaction for the gas-solid phase hybrid method.

体における構造解析には単結晶構造解析が望まれるため、 単結晶作製が必要である。通常、単結晶作製には容器とし て白金るつぼが用いられるが、白金は還元雲囲気に弱いた め、還元雲囲気での単結晶作製はあまり検討されていな い。そこで近年、当研究室では $1400{ }^{\circ} \mathrm{C}$ 以上の高温、強還 元䨌囲気下で安定して存在できる $\mathrm{SiO}$ ガスを $\mathrm{Si}$ 供給源と して、シードとなる $\mathrm{Eu}^{2+}$ を含むアルカリ土類金属炭酸塩を 反応させることで容易に蛍光体の単結晶を作製する手法を 開発した ${ }^{17)}$ 。これは、気相一固相ハイブリッド合成法と呼 ばれる単結晶育成法である。この合成手法の反応の模式図 を Fig.7 に示す。 $\mathrm{Ar} / \mathrm{H}_{2}$ などの強還元ガスを導入ガスとし て、その上流側に、 $\mathrm{Si}$ 供給源となる $\mathrm{SiO}_{2}$ 、下流側にシード となる発光イオンや母体結晶を形成する原料（炭酸塩、酸 化物など）の混合物をそれぞれ設置する。 $1400{ }^{\circ} \mathrm{C}$ 以上の高 温かつ $\mathrm{Ar}-\mathrm{H}_{2}$ などの強還元下で $\mathrm{SiO}_{2}$ が揮発し $\mathrm{SiO}$ ガスとな り ${ }^{18,19)}$ 、導入ガスにより下流のシードと反応し結晶成長す る。この手法により $\mathrm{Ba}_{2} \mathrm{SiO}_{4}: \mathrm{Eu}^{2+}$ の単結晶の作製に成功し ている ${ }^{17)}$ 。得られた単結晶蛍光体の SEM 画像を Fig.8 に示 す。得られた $\mathrm{Ba}_{2} \mathrm{SiO}_{4}$ : $\mathrm{Eu}^{2+}$ 単結晶は $40 \mu \mathrm{m}$ 程度の板状結晶 で、通常の固相反応法で合成した試料に比べて 12 倍以上の 粒子サイズであり、固相反応法で合成した試料に比べて約 2.6 倍の発光強度を示した。さらに、類似組成であり実用の LED 用黄色蛍光体である $\left(\mathrm{Ba}, \mathrm{Sr}_{2} \mathrm{SiO}_{4}: \mathrm{Eu}^{2+}\right.$ 蛍光体単結晶 も同方法によって育成し、単結晶 $\mathrm{X}$ 線構造解析により $\mathrm{Eu}^{2+}$ の配位環境を正確に特定した。従来、(Ba, $\mathrm{Sr}_{2} \mathrm{SiO}_{4}: \mathrm{Eu}^{2+}$ 中 の $\mathrm{Eu}^{2+}$ イオンは $\mathrm{Ba}$ 抢よび $\mathrm{Sr}$ サイトの両方に固溶されてい ると考えられてきたが、Srサイトのみに固溶されているこ とが明らかになった。

ナノ蛍光体は太陽電池の波長変換材や生体イメージング への応用が期待され、その需要が高まっている ${ }^{20}$ 。ナノ蛍 光体を含む十ノ材料は通常、溶液法をべースとした低温で の合成手法を用いて得られる。これは、加熱処理による結 晶成長を防ぐためである。溶液法は前述の通り、化学プロ セスに種々の操作を含むため、その合成プロセスの複雑化 によりコストが嵩んでしまう。この問題に対して当研究室 では、原料粉体に少量の水を添加し、室温から $100{ }^{\circ} \mathrm{C}$ 程度 の温度下で混合粉体を放置するのみで様々なナノセラミッ 


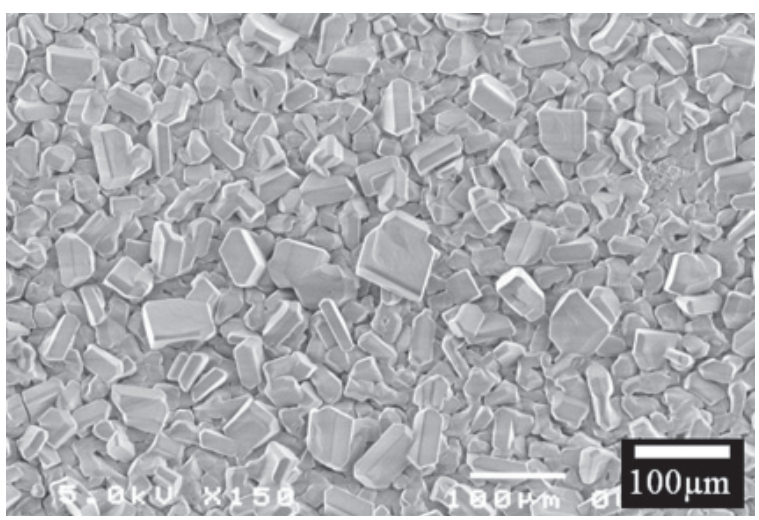

Fig.8 SEM image of the $\mathrm{Ba}_{2} \mathrm{SiO}_{4}$ : $\mathrm{Eu}^{2+}$ phosphor single crystal grown by a gas-solid phase hybrid method.

クス材料を得る新規合成方法を提案した ${ }^{211}$ 。この合成方法 は、わずかな水の添加が反応のカギとなることから、Water Assisted Solid State Reaction (WASSR) 法と名付けられてい る 22,23)。この合成法は、極好単純かつ容易にナノセラミッ クス粉体を合成することができる。WASSR 法で最も重要な のは、原料粉体の選択とその組み合わせである。たとえば、 同じ酸化チタンでもアナターゼ型とルチル型で反応速度が 顕著に異なることさえある。WASSR 法の合成方法としては、 まず、原料となる金属酸化物や炭酸塩、水酸化物などの沉 用的な粉体を化学量論比に従って秤量し、イオン交換水を $10 \mathrm{wt} \%$ 程度添加して乳鉢で混合する。このときに、均一に 反応を進行させるために、原料粉体を乾式で 1 分程度軽く 混合した後に水を添加する方が望ましい。また、化学組成 内に既に水を含んだ水酸化物などの水和物原料を取り扱う 場合は、水の添加が不要な場合もある。その後プラスチッ ク製の密閉容器に移し、室温下での反応の場合はそのまま 放置する（物質によっては混合の段階で反応が完結するこ ともあるため、保持のプロセスは必ずしも必要ではない) が、 熱処理をする場合は恒温機内で 24 時間（材料によってはそ れ以上) 程度保持する。 $80{ }^{\circ} \mathrm{C}$ 以下での加熱の場合は通常ポ リスチレンなどの汎用性の高いプラスチック容器で構わな いが、それを超える温度での加熱の場合は内圧が上昇する ため、ポリテトラフルオロエチレン (PTFE) 製の耐熱性の水 熱容器とオートクレーブを用いることが望ましい。

Table 1 にWASSR 法によって合成可能な代表的な酸化 物蛍光体材料とその原料、および反応温度を示す。 $\mathrm{RbVO}_{3}$ 抢よび $\mathrm{CsVO}_{3}$ は、母体結晶構造内の $\left[\mathrm{VO}_{4}\right]^{3-}$ イオンの電荷 移動遷移によって白色発光を示す、いわゆる母体発光蛍光 体であり、90\%以上の極めて高い内部量子効率を持つ蛍 光体として知られている ${ }^{21,24)}$ 。この蛍光体は、WASSR 法 の中でも最も単純に合成可能な蛍光体材料である。まず、 原料として $\mathrm{Rb}_{2} \mathrm{CO}_{3}$ 打よび $\mathrm{Cs}_{2} \mathrm{CO}_{3}$ と $\mathrm{V}_{2} \mathrm{O}_{5}$ を化学量論比に 従って秤量する。秤量後、メノウ乳鉢に原料を移し、約 10
Table 1 Typical nano-phosphors synthesized by a WASSR method.

\begin{tabular}{lll}
\hline Phosphors & Raw materials & Temperature $\left({ }^{\circ} \mathrm{C}\right)$ \\
\hline $\mathrm{MVO}_{3}(\mathrm{M}=\mathrm{Rb}, \mathrm{Cs})$ & $\mathrm{M}_{2} \mathrm{CO}_{3}+\mathrm{V}_{2} \mathrm{O}_{5}$ & 25 \\
$\mathrm{YVO}_{4}: \mathrm{Eu}^{3+}$ & $\mathrm{Y}_{2} \mathrm{O}_{3}+\mathrm{Eu}_{2} \mathrm{O}_{3}+\mathrm{V}_{2} \mathrm{O}_{5}$ & $25 \sim 80{ }^{\circ} \mathrm{C}$ \\
$\mathrm{SrMoO}_{4}: \mathrm{Eu}^{3+}$ & $\mathrm{SrCO}_{3}+\mathrm{MoO}_{3}+\mathrm{Eu}_{2} \mathrm{O}_{3}$ & $25{ }^{\circ} \mathrm{C}$ \\
$\mathrm{NaEu}\left(\mathrm{MoO}_{4}\right)_{2}$ & $\mathrm{Na}_{2} \mathrm{CO}_{3}+\mathrm{Eu}_{2} \mathrm{O}_{3}+\mathrm{MoO}_{3}$ & $80{ }^{\circ} \mathrm{C}$ \\
\hline
\end{tabular}

$\mathrm{wt} \%$ のイオン交換水を添加する。添加直後、発泡しなが ら激しく反応し、混合する過程で反応が完結する。十分に 混合された後は乾燥しているので、後処理の必要はない。 WASSR 法により得られた $\mathrm{CsVO}_{3}$ の SEM 画像を Fig.9 に示 す。WASSR 法により得られた粒子は粒子径が $100 \mathrm{~nm}$ 以下 の非常に細かい微粒子であったことから、ナノサイズ蛍光 体の作製方法として適していることがわかった。

$\mathrm{YVO}_{4}: \mathrm{Eu}^{3+}$ 蛍光体は 20 年以上にわたって、ブラウン管 などの電子線励起用のデバイスに打ける赤色成分として応 用されてきた ${ }^{25)}$ 。当研究室では、WASSR 法を用いることで $\mathrm{YVO}_{4}: \mathrm{Eu}^{3+}$ ナノ蛍光体の合成に成功した。 $\mathrm{YVO}_{4}$ : $\mathrm{Eu}^{3+}$ はす べて酸化物を原料として、10 wt\% のイオン交換水を添加し て合成することができる。ナノ蛍光体は、室温下で 1 分間 混合した後、ふた付きポリスチレン製密閉容器内に混合原 料を移し、 $80{ }^{\circ} \mathrm{C}$ の恒温機内で 24 時間保持することで得られ る。得られた試料を X 線回折により結晶相を同定したとこ ろ、一部原料酸化物が残存していたが、目的物がほぼ主相 で得られたことを確認した。Fig.10に WASSR 法および一 般の固相反応法を用いて得られた $\mathrm{YVO}_{4}$ : $\mathrm{Eu}^{3+}$ 蛍光体の SEM 画像を示す。一般の固相反応法で合成された試料は $2 \sim 3$ $\mu \mathrm{m}$ の粒子径であるのに対し、WASSR 法で合成された試料 は $100 \mathrm{~nm}$ 以下の極めて微小な粒子であった。これは、反応 が低温下で行われるため熱的なエネルギーが極めて小さく、 結晶成長が抑制されたためであると考えられる。

\section{5. おわりに}

本解説記事では、蛍光体材料に打ける沉用的かつ有用な 合成法である固相反応法ならびに基礎的な液相法に加え、 近年注目されている最新研究に扔ける手法について解説し た。特に、最も普遍的な固相反応法は基礎的であるからこ そ、様々な文献を見ても、これまでそのノウハウや細かい 作業的な注意点はほとんど述べられてきておらず、新たに 蛍光体研究に着手する研究者にとっては、高効率な蛍光体 開発は困難となっていた。原料や各装置、操作方法などの 基礎的な取り扱い、留意点などを述べることで、更なる蛍 光体開発の指針の一助となることを期待する。

蛍光体は、用途やその励起源によって求められる特性が 


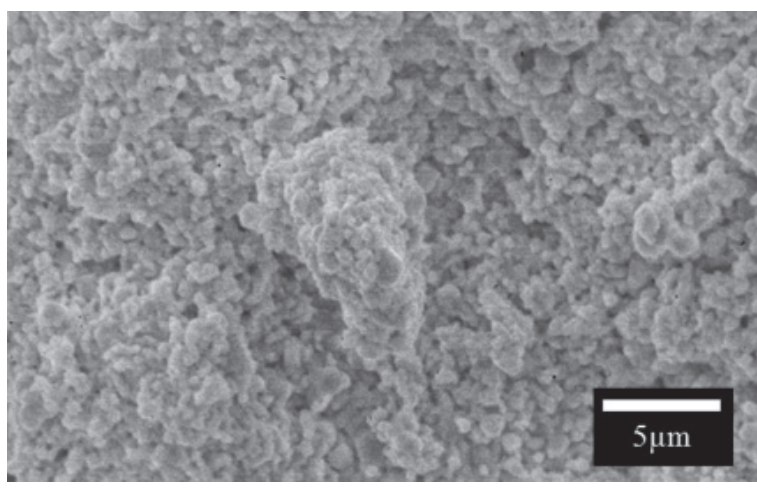

Fig.9 SEM image of $\mathrm{CsVO}_{3}$ phosphors synthesized by the WASSR method.

大きく異なってきており、それぞれの特性にかなう材料自 身の設計は勿論のこと、それと同等に材料の合成プロセス が重要である。近年の蛍光体の用途の多様化から、最新の 合成手法を取り入れた研究の活性化は蛍光体技術の向上に つながることが容易に予想できる。特に、蛍光体ナノ化技 術や複合化は、これまでの蛍光体の用途の大部分であった 「照明デバイス」とは一線を画した応用となる。たとえば、 太陽電池用の波長変換材や生体材料への検討が注目されて いる。これらの材料自体の研究が進み、実用のめどがたつ 頃には、その合成プロセスも確立されると予想されるので、 最新の材料の研究にも十分に注目し、トレンドを把握する 必要があると筆者らは考える。

\section{引用文献}

1) S. Shionoya: "Phosphor Handbook 2nd ed.", ed.by W.M. Yen, S. Shionoya and H. Yamamoto, CRC Press, 2006, p4.

2) 蛍光体同学会 : “蛍光体ハンドブック”、オーム社、(1987) 2-7.

3) 蛍光体同学会: “蛍光体ハンドブック”、オーム社、(1987) $8-33$.

4) S. Nakamura, T. Mukai and M. Senoh: Appl. Phys. Lett., 64 (1994) 1687-1689

5) 戸田健司、金善旭、石垣雅、亀井真之介、長谷川拓哉、上松和義、 佐藤峰夫：セラミックス、50 (2015) 144-155

6) S. Shionoya: "Phosphor Handbook 2nd ed.", ed.by W.M. Yen, S Shionoya and H. Yamamoto, CRC Press, 2006, p247-273.

7) M. Tabei, S. Shionoya and A. Suzuki: J. Appl. Phys., 14 (1975) 240247.

8) 垣花眞人、小林亮、加藤英樹、佐藤泰史、富田恒之：“無機材 料合成・探索法”、情報機構、(2014) 211-214.

9) Y. Sato, H. Kato, M. Kobayashi, T. Masaki, D.H.Yoon and M. Kakihana: Angew. Chem. Int. Ed., 53 (2014) 7756-7759.

10) M. Kakihana: J. Sol-Gel Tech. , 6 (1996) 7-55.

11) M. Kakihana: J. Ceram. Soc. Jpn., 117(2009)857-862.

12) 垣花眞人、小林亮、加藤英樹、佐藤泰史、冨田恒之：“無機材 料合成・探索法”、情報機構、(2014) 21-28.
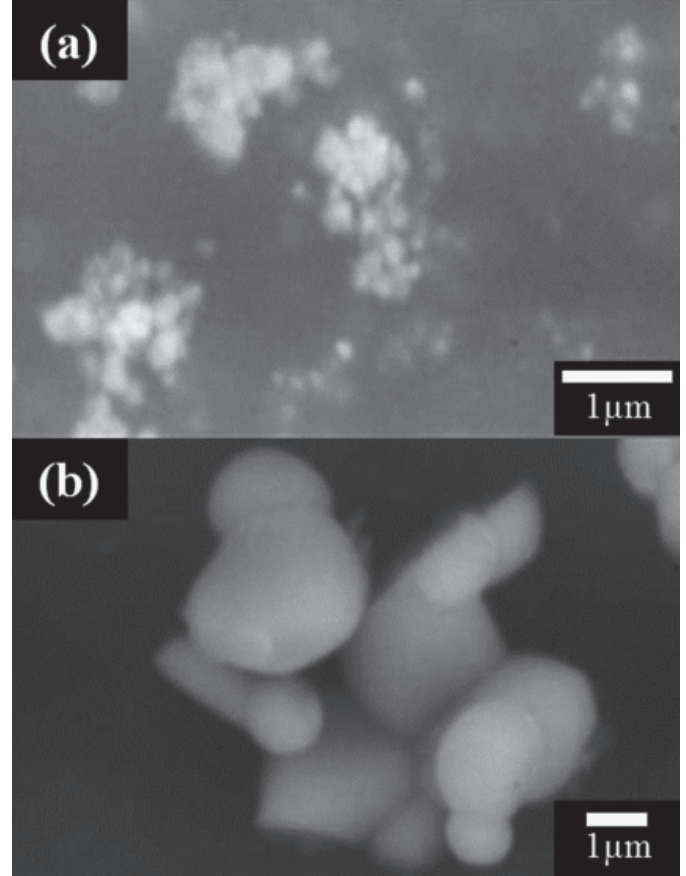

Fig.10 SEM images of $\mathrm{YVO}_{4}: \mathrm{Eu}^{3+}$ phosphors synthesized by (a) the WASSR method at $80{ }^{\circ} \mathrm{C}$ for $24 \mathrm{~h}$ and (b) the conventional solidstate reaction method at $1200{ }^{\circ} \mathrm{C}$ for $12 \mathrm{~h}$ in air.

13) M. Yoshimura, M. Nishioka, N. Ishizawa and S. Somiya: J. Mater. Sci. Lett., 9 (1990) 322-325.

14) T. Ishigaki, E. Nishimura, K. Seki, T. Watanabe and M. Yoshimura: J. Electroceram., 17 (2006) 885-889.

15) S. W. Kim, T. Hasegawa, T. Ishigaki, K. Uematsu, K. Toda and M. Sato: ECS Solid State Lett., 2 (2013) R49-R51.

16) S. W. Kim, T. Hasegawa, M. Inoue, T. Ishigaki, K. Uematsu, K. Toda and M. Sato: J. Ceram. Soc. Jpn, 122 (2014) 452-455.

17) T. Sakamoto, K. Uematsu, T. Ishigaki, K. Toda and M. Sato: J. Ceram. Process. Res., 12 (2011) s272-s274.

18) T.T. Stephan and A.P. Joseph: J. Am. Ceram. Soc., 65 (1982) 457460.

19) M.S. Crowley: Bull. Am. Ceram. Soc., 49 (1970) 527-530.

20) 大観光徳、石垣雅、大倉央：セラミックス、50 (2015)171-174.

21) 戸田健司、佐藤峰夫、上松和義、石坦雅：特開 2011-16670 (P2011-16670A).

22) T. Kaneko, S.W. Kim, A. Toda, K. Uematsu, T. Ishigaki, K. Toda, M. Sato, J. Koide, M. Toda, Y. Kudo, T. Masaki and D.H. Yoon: Sci Adv. Mater., 7 (2015) 1502-1505.

23) K. Toda, S.W. Kim, T. Hasegawa, M. Watanabe, T. Kaneko, A. Toda, A. Itadani, M. Sato, K. Uematsu, T. Ishigaki, J. Koide, M. Toda, Y Kudo, T. Masaki and D.H. Yoon: Key Eng. Mat., 690 (2016) 268271.

24) T. Nakajima, M. Isobe, T. Tsuchiya, Y. Ueda and T. Kumagai: Nat. Mater., 7 (2008) 735-740.

25 ) 蛍光体同学会 : “蛍光体ハンドブック”、オーム社、(1987) 247278. 